\title{
52 \\ Experiencing youth justice and penality
}

\author{
Siobhán McAlister and Nicola Carr
}

\section{Introduction}

Much of the recent literature on youth justice has focused on administrative aspects of the system and the socio-political contexts that have led to the 'production' of the youthful offender as a subject and locus of intervention. This has largely been driven by the extent to which youth justice has been crafted as a distinct penal sphere, evident in its unyoking from universal children's services (Muncie and Goldson, 2013) and the establishment of separate agencies to administer and govern this 'system' (Souhami, 2014). Driven by policy hyperactivity and a plethora of legislation expanding the reach of the system, for much of the 1990s and 2000s increasing numbers of young people were brought under its gaze.

Particular attention has been paid to the impact of neo-liberal governance on the discourses, rationales and philosophies underpinning contemporary youth justice policy and practice. Writing specifically in the English and Welsh context, several authors have identified that the resulting 'system' embodies multiple, contradictory and competing discourses (Muncie, 2006; Fergusson, 2007; Gray, 2013). Within this 'melting pot' Fergusson (2007) notes the disjuncture between policy rhetoric, implementation and lived experience and Phoenix (2016) argues that systems-based analyses, much in favour amongst academics, foreclose a wider consideration of questions of what 'justice' actually means.

Recent attention towards the perspectives of practitioners working in this sphere has pointed to greater nuances than broader penal narratives suggest (see Field, 2007; Briggs, 2013; Gray, 2013; Kelly and Armitage, 2015). Yet similar attention has not been given to experiences of youth justice (for an exception see Phoenix and Kelly, 2013). However, it is precisely young people's experiences, which would add significantly to current knowledge and potentially bridge the gap between discussions about penal philosophies, how youth justice policies are framed, how they are enacted and how they are experienced.

This chapter provides an overview of recent developments in the field of youth justice and penality in the United Kingdom. The chapter argues that a theoretical focus on macro-level trends (Hannah-Moffat and Lynch, 2012), alongside a narrowly defined research agenda, have largely excluded young people's experiences of justice and punishment from contemporary analysis. Drawing on young people's experiences of different aspects of youth justice in Northern 
Ireland and beyond, the chapter illuminates what a close understanding of lived experience can add to knowledge. In particular it demonstrates that the effects of interventions can be different from their aims and intentions; and that re-instating the youth experience can add support to calls for greater attention to wider issues of social justice.

\section{Recent trends in youth justice and penality: theory, policy and research}

Traditional accounts of youth justice have explored the inherent contradictions and tensions between welfare and justice-based approaches. On the one hand the differential status of young people is recognised by the existence of separate systems, on the other hand many suggest there is insufficient distinction between young people and adults within criminal justice (Muncie and Goldson, 2013). Despite some local divergence, the 1990s saw distinctions between youth and adult systems become less clearly delineated, and an expansion in the range and reach of the system resulting in greater numbers of young people brought under its ambit.

Alongside a 'punitive turn' contradictory and competing movements impacted on youth justice discourse internationally (Muncie, 2008). Increased recognition of victim's rights saw a resurgence of interest in restorative practices, and the ascendancy of the rights movement influenced diversionary and preventative approaches. As a consequence, the traditional debates about welfare and justice became less evident as the focus and underlying philosophies of youth justice and punishment became more complex. As Muncie and Goldson (2013: 342) note youth justice systems now comprise a range of rationales, including restoration, public protection, responsibilisation, child protection, rehabilitation and punishment, which 'intersect and circulate in a perpetually uneasy motion'.

These blended and shifting rationales or what Gray (2013: 517) describes as 'hybrid assemblages of penal governance' are reflective of late modern neo-liberalism. Concerns with ontological insecurity, the effective calculation and management of risk and strategies of individual responsibilisation have been identified as dominant in youth justice policy over the past two decades, particularly in England and Wales (Gray, 2005; Kemshall, 2008; Briggs, 2013; Phoenix and Kelly, 2013). Youth offending and its prevention became understood in terms of narrowly defined quantifiable indicators of risk through the adoption of the Risk Factor Prevention Paradigm (Farrington, 1996). The raft of early intervention and prevention programmes informed by this approach are similarly narrowly focused on behaviour management, locating primary responsibility for change in young people and their families (see Kemshall, 2008; Haydon, 2014). Structural factors which had always been 'key determinants in the world of risk inhabited by young people' (Kemshall, 2008: 31) became sidelined.

A 'new' research agenda developed feeding off and into these policy imperatives. Despite a healthy catalogue of existing research, Goldson (2010) notes how some forms of knowledge became prioritised and privileged. Incorporating the actuarial focus of measurement and management of risk, the policy mantra of 'evidence-based policy and practice', prioritises 'scientific' evidence which aids in calculating risk and assessing 'what works' in managing it. In this logic, experiential forms of knowledge become viewed as subjective, and research based on practice and experience of youth justice and penality becomes marginalised. The production and value placed on particular forms of evidence limits the analysis to pre-defined interests and assumptions (Phoenix, 2010). In doing so the context and complexity of young people's lives is ignored, and larger questions about the aims, ethos and desirability of interventions do not feature (Phoenix, 2010; Hines, 2010).

The hierarchy of knowledge is also essentially self-replicating - policy drives research and research feeds back into policy, not only legitimising policy initiatives but maintaining the same 
narrow focus of analysis (Phoenix, 2010). Ranking low in the hierarchy, the practitioner voice and practice experience have also been demoted resulting in gaps in understanding how recent developments have translated into practice (or indeed have been subverted). As macro-level analysis of penal trends have been a focal point micro-level localised practices and processes have received less attention (Hannah-Moffat and Lynch, 2012). This is despite the fact that practice (and experience) cannot be directly 'read-off' policy or dominant ideologies (Smith, 2011: 127). Research starting to address this gap, suggests some disjuncture between policy rhetoric, dominant ideologies and professional practice (Briggs, 2013; Gray, 2013).

Much has, therefore, been written and theorised about contemporary youth justice and penality. How multiple and competing discourses are experienced by young people, the complexities, challenges, contradictions and, indeed, the consistencies in contemporary experiences of youth justice are, however, less well known (McAlister and Carr, 2014). Yet a focus on subjective experiences, how young people experience different punishments, interventions and interactions, can reveal how intended aims and philosophies translate into practice. That 'microsite studies' have found that interventions can have unintended effects, demonstrates the value of reintroducing 'the social actor into empirical analysis' (Phoenix and Kelly, 2013: 426). Further, it allows for a close examination of the meaning of 'punitiveness' in the lived realities of young people.

These are some of the issues this chapter will examine through a consideration of young people's experiences of justice and punishment. The chapter is framed by findings from a qualitative study conducted in Northern Ireland, which used a life-history approach to explore young people's life experiences and contact with the youth justice system. Details of the study are reported in McAlister and Carr (2014). The following sections elaborate on the concept of 'punitive lives' before discussing young people's experiences of two forms of 'justice' - restorative and custody.

\section{Experiencing justice and punishment}

\section{Punitive lives and environments}

Rios (2011) employs the concept of 'punitive environments' to refer to the harsh and punishing nature of the communities marginalised young people encounter. In addition to disproportionate risk of contact with official agents of social control, such as police, courts and prisons, he includes punitive experiences in the neighbourhood, family and school. Examples of punitive encounters are replete in the accounts of young people in contact with the criminal justice system. Such encounters in one sphere can exacerbate exclusion and processes of criminalisation in other spheres (Rios, 2011). Evidence of the connection between social vulnerability and offending is apparent in the life histories of young people who have been processed through the youth justice system in Northern Ireland (Carr and McAlister, 2015). The complex and punitive nature of their lives - the risks they experience, the punitive environments within which they live and the social control to which they are subjected - were overt in discussions relating to housing, family, community and policing.

The intersection between offending and victimisation is well evidenced (see, for example, Smith, 2004). Multiple experiences of adversity are regularly apparent in the biographies of young people who offend, including family/domestic violence, parental alcohol misuse, bereavement, community violence, experiences of care, unstable housing situations and punitive policing (Goldson, 2005; Jacobson et al., 2010; Carr and McAlister, 2015). The impact of chaotic, complex and punitive lives on the processes of criminalisation is, therefore, well 
recognised. For example, exclusion from school can lead to more time spent on the streets, which can bring young people to the attention of the police. Difficult family relationships can impact on the custodial experience through lack of visits or restricted access to a bail address for young people remanded to custody. While punitive encounters and environments may be culturally and geographically specific, the manner in which they can exacerbate feelings and experiences of exclusion and fuel processes of criminalisation are similar.

Punitive environments are also shaped by social, cultural and historical factors. Taking Northern Ireland as an example, the particular circumstances of a thirty-year-long political Conflict and its legacies influence in part the punitive risks, encounters and environments that marginalised young people experience in their everyday lives. As materially deprived communities, from which most young offenders are drawn, were disproportionately affected by the Conflict - in terms of deaths, injuries, levels of violence, the withdrawal of services, informal paramilitary policing - they continue to experience the legacies in the early stages of transition (see McAlister and Healy, 2016). This includes limited resources and opportunities, (conflictrelated) mental ill-health and transgenerational trauma impacting family life and relationships, and 'low-level' but constant threats of paramilitary and sectarian-related violence.

It is perhaps unsurprising, then, that in our study over half of the sample reported direct victimisation by paramilitaries in the form of verbal threats, threats with weapons, physical intimidation, assault and exiling/exclusion from their communities (McAlister and Carr, 2014). This informal method of crime control and behaviour management (Brewer et al., 1997), a legacy of the Conflict, regularly focuses on young people who are deemed 'anti-social', 'anticommunity' or 'criminal' (Smyth et al., 2004). Given the offending history of some, punitive encounters with paramilitaries could be multiple and coincide with interventions and punishment from formal systems of justice. In this extract Séan, a 17 year old remanded in custody, describes his experiences of 'paramilitary punishment' for his involvement in 'anti-social' behaviour in his community:

Yeah I've took a beating from them [paramilitaries] before but not to the extent were they beat me and left me for dead. They've beat me with baseball bats twice but I just didn't I was kid and I didn't care. I was taking the beating and then I was going and doing it again.

Notably young people who experience such harsh forms of 'arbitrary' justice did not report their experiences to the police. In this specific context, poor relationships with the police are in part the legacy of the Conflict, but research elsewhere similarly records the phenomena of 'over policing' and 'under protection' of marginalised young people (particularly ethnic minorities) (McAra and McVie, 2005; Sharp and Atherton, 2007). Therefore while some young people are the victims of serious intimidation and violence within their communities, their victimisation remains hidden. Punishment outside the formal justice system, layered over judicial punishment, not only demonstrates that some young people are subject to multiple forms of 'justice', but at the same time access to justice is not perceived possible to young people themselves (Carr and McAlister, 2015).

Evidently young people's sense of justice and injustice will be mediated by such life experiences. Their interactions with agencies and interventions under the rubric of 'youth justice' are filtered through this. Such experiences of 'youth justice' cannot be removed from contexts of multiple harms and adversities. In the next sections we discuss young people's experiences of restorative justice and custody in light of this. 


\section{Experiencing restorative justice}

International children's rights frameworks endorse restorative responses to young people in conflict with the law (Muncie, 2005; Moore and Mitchell, 2009; Lynch, 2010). Advocates of restorative justice note the benefits of less formality, more inclusivity and wider participation in a process that ideally involves victim, offender and the wider community (Morris, 2002). The stated aim of restorative justice is to 'restore the harm caused by offending', but the extent to which this is a realistic objective for all who experience 'harm' (victim, 'offender', community) is queried (see Daly, 2013 for an overview). Furthermore, in many contexts, restorative justice approaches have been grafted on to conventional criminal justice systems (Doak and O'Mahony, 2011). Consequently distinguishing between 'restorative' and conventional criminal justice responses can be difficult.

Restorative justice literature is 'bursting at the seams' with programme evaluations and frameworks of 'best practice' (Bolitho, 2012: 76). Outcomes focused evaluations tend to report success through measurements of (short-term) re-offending and participant satisfaction (Bolitho, 2012). Experiential accounts, however, are more mixed. Some demonstrate the disjuncture between underlying philosophy and subjective experience (Newbury, 2008), and produce findings that question both the intended effects and the proportionality of these sanctions (McAlister and Carr, 2014). Despite the disassociation with retribution (at least by some proponents see Daly, 2013), some young people experience restorative justice as punitive, stigmatising and exclusionary both in process and outcome (McAlister and Carr, 2014).

A deeper examination of the meaning, process and subjective experience of justice allows for an analysis of the intersection of varying penal practices (Hannah-Moffat and Maurutto, 2012), demonstrating how different discourses from those intended can take precedence. While grounded in multiple rationales, responsibilisation has been found most prominent in recent examinations of the experience of restorative justice (McAlister and Carr, 2014; Gray, 2005). The prominence of restorative responses to young people in conflict with the law, therefore, does not necessarily signal the erosion of punishment (Hannah-Moffat and Maurutto, 2012), but the melding together of various penal practices with some featuring more prominently than others.

Because restorative justice so clearly delineates between 'victim' and 'offender' it creates a dichotomy where young people's own experiences of victimisation are sidelined. Further, the narrow definition of 'harm' employed in practice means that the reintegrative potential is restricted. Repairing harm is weighted in favour of the immediate and 'legitimate' victim and the social harms, injustices and victimisation experienced by 'the offender' and the restoration of their 'dignity, power and freedom' (Mahaffrey, 2010: 123) take less precedence. Strategies of responsibilisation are central to the official youth justice discourse and young people's offending narratives are often replete with expressions of self-blame and personal accountability (McAlister and Carr, 2014). While regularly accepting responsibility and engaging in reparative tasks, the social economic and cultural contexts of young people's lives calls into question the meaning of, and potential for, reintegration in practice (Gray, 2005; Lynch, 2010).

Young people's experiences of restorative interventions highlight this in practice. Hugh had been the subject of multiple restorative justice conferences and described how he found it difficult to recount offences because of drug use. The conference plan required him to undertake 'offending programmes', but he expressed frustration that ultimately there was no support for what he considered his main difficulty:

It was just stuff that I had to do, court order like programmes like ... offending programmes and all that help reduce offending, you know just stupid programmes like that. No 
programmes about drugs and like there was no people to help you with the drugs and there was just no one to help me that way. I just, dunno.

(Hugh, age 16)

For Jennifer who had been convicted of an assault on another young person (a conviction that she disputed), the process of having to 'beg' to have her apology accepted was humiliating:

Aye, and it was more hard as well because like, you never really want to say sorry to anybody, and I kind of like had to beg and beg for her to like accept my apology cause I didn't want to come in here at all.

(Jennifer, age 15)

Young people's sense of injustice at the process of restorative justice is particularly evident when they feel their experiences are not afforded due weight, especially given the punitive contexts of many of their lives (McAlister and Carr, 2014). These issues are important given that restorative justice is not only about restoration, but also about 'doing justice' (Walgrave, 2004). Containing discourses of retribution, responsibilisation and prevention as well as rights, restoration, welfare and reintegration, the performance of restorative justice epitomises the multiple and competing discourses of youth justice.

\section{Experiencing bail, custody and remand}

International human rights standards advise custody should be used as a measure of last resort for young people in conflict with the law. Research consistently demonstrates that the custodial population contains some of society's most disadvantaged young people, and that the custodial experience is also harmful (Goldson, 2005). Custody is, therefore, "deemed one of the most punitive responses to youth offending. Experiences of custody, including remand, are, however, also mediated by the wider context of young people's lives. A lack of supports can, for example, impact on the length and nature of custodial remand, the complexity of young people's lives can impact on their ability to adhere to bail conditions and the punitive risks they experience in everyday life can impact on experiences of custody (Carr and McAlister, 2015).

An analysis of lives 'in the round' can, therefore, reveal much about how young people experience custody, remand and bail. Unstable family and housing circumstances, limited supports and a lack of appropriate bail or homeless accommodation, for example, mean that some young people are remanded to custody rather than granted bail. While remand to custody is recognised as stigmatising and disruptive to relationships, work and education commitments (Stubbs, 2010), it is regularly a 'stop gap' for children who are in need and at risk, thus disadvantaging the already disadvantaged.

Added to this, when bail is granted, the conditions placed on some young people are so restrictive, onerous and/or inappropriate that breach and re-remand to custody is inevitable. This is particularly the case when inappropriate conditions are placed for long periods on those who have problematic drug or alcohol use, chaotic and unsettled lives (Carr and McAlister, 2015). In legal terms bail conditions are not intended as a punishment. They are imposed when there are grounds for refusing bail and where a judge assesses that adding conditions are necessary for a young person to remain in the community. Yet there is evidence that bail conditions can be punitively set and regulated 'not always proportional or even relevant to the risk of further offending' (YJRT, 2011: 85; see also Stubbs, 2010).

Monitoring and compliance checking can be experienced as intrusive and harassing, playing a part in breach. Take the experience of Stevie (aged 16) whose conditions included an 
electronically monitored curfew (wearing a tag), the imposition of a geographical exclusion, a ban on alcohol use, reporting to the police station and required attendance at the Youth Justice Agency twice a week, a home visit once a week and meeting a mentor three times a week. In addition:

They [the police] still call to me house all the time like, you know breathalise me and all because of me tag and ask me to show them my tag and all... They know that I'm in cos if that tag was outside after nine o'clock, or it's not in after nine, that goes straight through to the [police] barracks.

Intensive supervision and surveillance in the community can blur the boundary between community and custody. So onerous are the conditions of bail for some, added to the risks and adversities of their daily lives, that they express a preference for remand in custody over bail to the community (Carr and McAlister, 2015). Thus, a contingent community existence can be viewed as more punitive than custody. While bail is seen as desirous for young people and compliant with human rights frameworks, experiences of bail reveal that conditions and monitoring in the context of already punitive lives, can be intrusive and punishing in nature.

The punitive nature of the personal, family and community lives of young people in conflict with law can also impact variably on experiences of custody. For some, lack of family visits and supports, concern for their welfare upon release and/or withdrawal from drugs or alcohol can make the experience of custody particularly punitive. Conversely, that the worries of everyday life and the temptation of drugs and alcohol are removed can mean that custody is experienced as a period of respite. Demonstrating the nature of his life outside, Robbie (aged 17) explained that in custody: 'You've no worries about people looking for you, no worries about nothing. You've no worries about 'going looking and getting food and shit like that' (Carr and McAlister, 2015). Experiences of custody can, therefore, be both punitive and welfarist given that needs are met here that are not met elsewhere. While this highlights the deficits in community-based provision and the punitive nature of young people's lives, rather than any inherent benefits of custody, it further demonstrates disjuncture between youth justice discourse and penal experience, and how penal experiences are mediated by social, cultural and structural factors.

\section{Conclusion}

The social context of young people's lives impacts on experiences of school, attitudes towards and contact with the police, and experiences of crime as victims and offenders (Carr and McAlister, 2015). Social injustices and wider social harms can shape contact with the criminal justice system (Yates, 2010; Smith, 2011) as well as the experience of justice, impacting on how interventions and interactions are 'felt' and a sense of 'justice' is perceived (McAlister and Carr, 2014). Yet experiences of justice and injustice (including victimisation) rarely feature in contemporary policy discourse, or in the 'evidence-based' research agenda. As such, an understanding of how justice and punishment are 'experienced' (as opposed to intended), does not feed into policy making. This is despite critical research demonstrating the potential disjuncture between discourse, practice and experience. Some interventions based on welfare principles are, for example, experienced coercively and punitively (McAra, 2006), those justified on the basis of the best interests of the child can be intrusive and criminalising (Fergusson, 2007) and those premised on early intervention and prevention can be a route into the criminal justice system for children with unmet need (Haydon, 2014). 
A deeper analysis of youth justice interventions and how these are experienced can, therefore, provide an understanding beyond intended philosophies and that revealed by narrowly defined research. Further, it can illuminate the outworkings of hybrid and sometimes contradictory discourses and allow for an examination of the impacts of wider penal trends (of responsibilisation and punitiveness) on a range of youth justice interventions. Perhaps most importantly it can focus more closely on the need to consider wider questions of social justice

\section{References}

Bolitho, J. (2012) 'Restorative Justice: The Ideals and Realities of Conferencing for Young People', Critical Criminology, 20: 61-78.

Brewer, J., Lockhart, B. and Rodgers, P. (1997) Crime in Ireland 1945-1995: Here be Dragons, Oxford: Clarendon Press.

Briggs, D. (2013) 'Conceptualising Risk and Need: The Rise of Actuarialism and the Death of Welfare? Practitioner Assessment and Intervention in the Youth Offending Service', Youth Justice, 13 (1): 17-30.

Carr, N. and McAlister. S. (2015) 'Experiencing Youth Justice: Process, Meaning and Legitimacy'. Policy Briefing for the Northern Ireland Assembly. Available at: www.niassembly.gov.uk/globalassets/ documents/raise/knowledge_exchange/briefing_papers/series4/carr-and-mcalister-kess-policybriefing.pdf.

Daly, K. (2013) 'The Punishment Debate in Restorative Justice'. In: J. Simon and R. Sparks (eds) The Sage Handbook of Punishment and Society. London: Sage (pp. 356-374).

Doak, J. and O'Mahony, D. (2011) 'In Search of Legitimacy: Restorative Youth Conferencing in Northern Ireland', Legal Studies, 31 (2): 305-325.

Farrington, D. (1996) 'Understanding and Preventing Youth Crime: Findings', Social Policy Research 93, April 1996, York: Joseph Rowntree Foundation.

Fergusson, R. (2007) 'Making Sense of the Melting Pot: Multiple Discourses in Youth Justice Policy', Youth Justice, 7 (3): 179-194.

Field, S. (2007) 'Practice Cultures and the "New" Youth Justice in (England and) Wales', British Journal of Criminology, 47 (2): 311-330.

Goldson, B. (2005) 'Child Imprisonment: A Case for Abolition', Youth Justice, 5 (2): 77-90.

Goldson, B. (2010) 'Research-informed Youth Justice'. In: W. Taylor, R. Earle and R. Hester (eds) Youth Justice Handbook: Theory, Policy and Practice, Cullompton: Willan Publishing, pp. 64-72.

Goldson, B. and Muncie, J. (2008) 'Children in Custody'. In: B. Goldson (ed.) Dictionary of Youth Justice, Cullompton: Willan, pp. 62-64.

Gray, P. (2005) 'The Politics of Risk and Young Offenders' Experiences of Social Exclusion and Restorative Justice', British Journal of Criminology, 45 (6): 938-957.

Gray, P. (2013) 'Assemblages of Penal Governance, Social Justice and Youth Justice Partnerships', Theoretical Criminology, 17 (4): 517-534.

Hannah-Moffat, K. and Lynch, M. (2012) 'Theorizing Punishment's Boundaries: An Introduction', Theoretical Criminology, 16 (2): 119-121.

Hannah-Moffat, K. and Maurutto, P. (2012) 'Shifting and Targeted Forms of Penal Governance: Bail, Punishment and Specialized Courts', Theoretical Criminology, 16 (2): 201-219.

Haydon, D. (2014) 'Early Intervention for the Prevention of Offending in Northern Ireland', Youth Justice, 14 (3): 226-240.

Hines, J. (2010) 'Young People's “Voices” as Evidence'. In: W. Taylor, R. Earle and R. Hester (eds) Youth Justice Handbook: Theory, Policy and Practice, Cullompton: Willan Publishing, pp. 168-178.

Jacobson, J., Bhardwa, B., Gyateng, T., Hunter, G. and Hough, M. (2010) Punishing Disadvantage: A Profile of Children in Custody, London: Prison Reform Trust.

Kelly, L. and Armitage, V. (2015) 'Diverse Diversions: Youth Justice Reform, Localized Practices, and a “New Interventionist Diversion”?' Youth Justice, 15 (2): 117-133.

Kemshall, H. (2008) 'Risk, Rights and Justice: Understanding and Responding to Youth Risk', Youth Justice, 8 (1): 21-37.

Lynch, N. (2010) 'Restorative Justice through a Children's Rights Lens', International Journal of Children's Rights, 18: 161-183. 
McAlister, S. and Carr, N. (2014) 'Experiences of Youth Justice: Youth Justice Discourses and their Multiple Effects', Youth Justice, 14 (3): 241-254.

McAlister, S. and Healy, D. (2016) 'Crime, Conflict and Poverty'. In: D. Healy, C. Hamilton, Y. Daly and M. Butler (eds) The Routledge Handbook of Irish Criminology. London: Routledge, pp. 124-143.

McAra, L. (2006) 'Welfare in Crisis? Key Developments in Scottish Youth Justice'. In: J. Muncie and B. Goldson (eds) Comparative Youth Justice, London: Sage, pp. 127-145.

McAra, L. and McVie, S. (2005) 'The Usual Suspects? Street-Life, Young People and the Police', Criminology and Criminal Justice, 5 (1): 5-36.

Mahaffrey, H. (2010) 'Restorative Justice at the Heart of the Youth Community'. In: W. Taylor, R. Earle and R. Hester (eds) Youth Justice Handbook: Theory, Policy and Practice, Cullompton: Willan Publishing, pp. 123-131.

Moore, S. and Mitchell, R. (2009) 'Rights-based Restorative Justice: Evaluating Compliance with International Standard', Youth Justice, 9 (1): 27-43.

Morris, A. (2002) 'Critiquing the Critics: A Brief Response to Critics of Restorative Justice', British Journal of Criminology, 42 (3): 596-615.

Muncie, J. (2005) 'The Globalization of Crime Control: The Case of Youth and Juvenile Justice: Neoliberalism, Policy Convergences and International Conventions', Theoretical Criminology, 9 (1): 35-64.

Muncie, J. (2006) 'Governing Young People: Coherence and Contradiction in Contemporary Youth Justice', Critical Social Policy, 26 (4): 770-793.

Muncie, J. (2008) 'The Punitive Turn in Juvenile Justice: Cultures of Control and Rights Compliance in Western Europe and the USA', Youth Justice, 8 (2): 107-121.

Muncie, J. and Goldson, B. (2013) 'Youth Justice: In a Child's Best Interests?' In: R. Sparks and J. Simon (eds) The Sage Handbook of Punishment and Society, London: Sage, pp. 341-355.

Newbury, A. (2008) 'Youth Crime: Whose Responsibility?' Journal of Law and Society, 35 (1): 131-149.

Phoenix, J. (2009) 'Beyond Risk Assessment: The Return of Repressive Welfarism'. In: M. Barry and F. McNeill (eds) Youth Offending and Youth Justice, London: Jessica Kingsley, pp. 113-131.

Phoenix, J. (2010) 'Whose Account Counts? Politics and Research in Youth Justice'. In: W. Taylor, R. Earle and R. Hester (eds) Youth Justice Handbook: Theory, Policy and Practice, Cullompton: Willan Publishing, pp. 73-82.

Phoenix, J. (2016) 'Against Youth Justice and Youth Governance, for Youth Penality', British Journal of Criminology, 56 (1): 123-140.

Phoenix, J. and Kelly, L. (2013) "“You Have to Do it Yourself": Responsibilization in Youth Justice and Young People's Situated Knowledge of Youth Justice Practice', British Journal of Criminology, 53 (3): 419-437.

Rios, V. (2011) Punished: Policing the Lives of Black and Latino Boys, New York: New York University Press.

Sharp, D. and Atherton, S. (2007) 'To Serve and Protect? The Experiences of Policing in the Community of Young People from Black and Other Ethnic Minority Groups', British Journal of Criminology, 47 (5): 746-763.

Smith, D. (2004) The Links between Victimisation and Offending, Edinburgh: Centre for Law and Society, University of Edinburgh.

Smith, R. (2011) Doing Justice to Young People: Youth Crime and Social Justice, Cullompton: Willan Publishing.

Smyth, M., Fay, M.T., Brough, E. and Hamilton, J. (2004) The Impact of Political Conflict on Children in Northern Ireland, Belfast: Institute for Conflict Research.

Souhami, A. (2014) 'Creating the Youth Justice Board: Policy and Policy Making in England and Welsh Youth Justice', Criminology and Criminal Justice, 15 (2): 152-168.

Stubbs, J. (2010) 'Re-examining Bail and Remand for Young People in NSW', Australian and New Zealand Journal of Criminology, 43 (3): 485-505.

Walgrave, L. (2004) 'Restoration in Youth Justice', Crime and Justice, 31: 543-597.

Yates, J. (2010) 'Structural Disadvantage: Youth, Class, Crime and Poverty'. In: W. Taylor, R. Earle and R. Hester (eds) Youth Justice Handbook: Theory, Policy and Practice, Cullompton: Willan Publishing, pp. 5-22.

Youth Justice Review Team (YJRT) (2011) A Review of the Youth Justice System in Northern Ireland, Belfast: YJRT.

1 